\title{
Responsiveness to societal needs in postgraduate medical education: the role of accreditation
}

\author{
Ingrid Philibert ${ }^{1 *}$ and Danielle Blouin ${ }^{2}$
}

\begin{abstract}
Background: Social accountability in medical education has been defined as an obligation to direct education, research, and service activities toward the most important health concerns of communities, regions, and nations. Drawing from the results of a summit of international experts on postgraduate medical education and accreditation, we highlight the importance of local contexts in meeting societal aims and present different approaches to ensuring societal input into medical education systems around the globe.

Main text: We describe four priorities for social responsiveness that postgraduate medical education needs to address in local and regional contexts: (1) optimizing the size, specialty mix, and geographic distribution of the physician workforce; (2) ensuring graduates' competence in meeting societal goals for health care, population health, and sustainability; (3) promoting a diverse physician workforce and equitable access to graduate medical education; and (4) ensuring a safe and supportive learning environment that promotes the professional development of physicians along with safe and effective patient care in settings where trainees participate in care. We relate these priorities to the values proposed by the World Health Organization for social accountability: relevance, quality, cost-effectiveness, and equity; discuss accreditation as a lever for change; and describe existing and evolving efforts to make postgraduate medical education socially responsive.
\end{abstract}

Conclusion: Achieving social responsiveness in a competency-based postgraduate medical education system requires accrediting organizations to ensure that learning emphasizes relevant competencies in postgraduate curricula and educational experiences, and that graduates possess desired attributes. At the same time, institutions sponsoring graduate medical education need to provide safe and effective patient care, along with a supportive learning and working environment.

Keywords: Accreditation, Diversity, Equity, Postgraduate medical education, Societal accountability

\section{Background}

The medical education enterprise is accountable to the citizens who will be served by the physician workforce it produces [1]. An appropriately sized, skilled, and distributed physician workforce is critical to the health of any nation. The composition and skill set of this workforce

\footnotetext{
* Correspondence: ingrid.philibert@quinnipiac.edu

'Department of Medical Education, Frank H. Netter MD School of Medicine at Quinnipiac University, North Haven, CT, USA

Full list of author information is available at the end of the article
}

is determined in significant part during the postgraduate phase of medical education. Three decades ago, the World Federation for Medical Education (WFME) declared that the aim of medical education is to produce physicians who will promote the health of all people, and noted that this aim was not being met despite progress in medical science [2]. In 1995, the World Health Organization (WHO) defined the social accountability of medical schools as "the obligation to direct their education, research and service activities towards addressing

(c) The Author(s). 2020 Open Access This article is licensed under a Creative Commons Attribution 4.0 International License, which permits use, sharing, adaptation, distribution and reproduction in any medium or format, as long as you give appropriate credit to the original author(s) and the source, provide a link to the Creative Commons licence, and indicate if changes were made. The images or other third party material in this article are included in the article's Creative Commons licence, unless indicated otherwise in a credit line to the material. If material is not included in the article's Creative Commons licence and your intended use is not permitted by statutory regulation or exceeds the permitted use, you will need to obtain permission directly from the copyright holder. To view a copy of this licence, visit http://creativecommons.org/licenses/by/4.0/ The Creative Commons Public Domain Dedication waiver (http://creativecommons.org/publicdomain/zero/1.0/) applies to the data made available in this article, unless otherwise stated in a credit line to the data. 
the priority health concerns of the community, region, and/or nation they serve" [3]. Medical education and accreditation experts discussed the importance of social accountability at the 2013 World Summit on OutcomesBased Accreditation. ${ }^{1}$ Participants at the summit discussed the role of accreditation in a wide range of domains, focusing on the accreditation systems in different nations, including the United States, Canada, and the Netherlands. In this article, we propose "social responsiveness" as a more actionable term for postgraduate medical education, given its relatively decentralized operation in most nations' health care systems. Social responsiveness has been defined as the "engagement in a course of actions responding to social needs" [4]. Inherent in the WFME and WHO definitions of social accountability are expectations for the competencies of the physician workforce that the medical education system produces. Yet the general nature of the definitions makes it challenging to translate them into actionable recommendations for postgraduate medical education programs and institutions. The term "responsiveness" is congruent with the WHO expectation that health care priorities should be collectively identified by stakeholders, including governments, health care organizations, educators, professionals, and members of the public [3].

\section{Main text}

Social responsiveness in postgraduate medical education In contrast to earlier commentators who have discussed social accountability expectations for medical schools, we focus on physician education after medical school and describe four priorities for social responsiveness in the postgraduate medical education system. The first pertains to ensuring that the size, specialty mix, and geographic distribution of the physician workforce is adequate to meet patient and population health needs $[5,6]$. The second priority pertains to the skill set necessary to enable the profession to meet societal goals for access, population health, and the stewardship of resources [7] while addressing health disparities [8] and the social determinants of health [9] in increasingly diverse populations. The third priority relates to enhancing the diversity and inclusiveness of the learning environment; this includes increasing the representation of racial, ethnic, and other minorities in the physician workforce and promoting an inclusive and

\footnotetext{
${ }^{1}$ This discussion, held at the 2013 World Summit on Outcomes-Based Accreditation in Calgary, Alberta, in conjunction with the International Conference on Residency Education, included representation across the continuum of medical education (undergraduate, postgraduate, and continuous professional development) and from a number of nations. The participants, who represented a variety of roles in medical education and accreditation, included current and former program directors and deans, senior administrators, and accreditors.
}

supportive environment for all trainees. The fourth priority pertains to ensuring a safe, respectful, and supportive learning and working environment that facilitates the professional development of physicians while providing safe and effective care in settings where trainees learn and participate in care. Detail on the four priorities is shown in Tables 1, 2, 3 and 4. Three of the priorities relate to the future physician workforce, and one to the learning environment that provides the context for the professional socialization of the future physician workforce. These priorities complement Boelen's social obligation scale and facilitate its operationalization [4].

\section{Approaches to meeting social responsiveness aims}

In Tables 1, 2, 3 and 4, we summarize interventions at the level of the system (government entities and accreditors), the institution and program, and the individual to address the four priorities. This highlights accreditation as a lever for social accountability in many domains. We relate the social responsiveness priorities we identified to four values for social accountability discussed in a 1995 WHO document: (1) relevance (the degree to which the aims of medical education are congruent with the needs and aims of the communities it serves); (2) quality (the degree to which medical education contributes to highquality, effective care, both in the settings where trainees participate in care and in graduates' future practice); (3) cost-effectiveness (the extent to which medical education contributes to cost-effective care); and (4) equity (making health care available to all, and making medical education accessible to women and members of racial, ethnic, and other minorities) [3].

The four social responsiveness priorities shown in Tables 1, 2, 3 and 4 are not new, and many of the aspects summarized there are congruent with a consensus document on the social responsibility of medical schools [26]. Yet, despite a general appreciation and considerable agreement on dimensions of social accountability, few studies have broadly addressed social responsiveness in postgraduate medical education. Work to date has focused on efforts to address a single aspect, such as optimizing the size and distribution of the physician workforce [27], enhanced funding for primary care and rural training programs [28], and service learning projects to expose learners to settings that provide care for underserved patients [29]. Efforts to enhance the postgraduate learning and working environment have focused on trainee work hour limits [30, 31] and interventions to promote a safe, effective, and supportive learning environment [12].

Suggestions for broader interventions have generally been made at the conceptual level, such as proposals in the United States to reallocate funding for graduate medical education to incentivize programs that meet social accountability aims [32], and some commentators 
Table 1 Priority 1: Appropriate size, specialty mix, and geographic composition of the physician workforce

\begin{tabular}{ll}
\hline Interventions & $\begin{array}{l}\text { Benefits to the health care system } \\
\text { (relevant social accountability values) }\end{array}$ \\
\hline $\begin{array}{l}\text { Ensure appropriate size, specialty mix, } \\
\text { and skill set of the physician workforce }\end{array}$ & $\begin{array}{l}\text { Improved access to care for all individuals; } \\
\text { improved population health } \\
\text { (relevance, equity) [3] }\end{array}$
\end{tabular}

Optimize geographic distribution of physicians
Access to care and improved population health for rural and underserved inner-city populations (relevance, equity) [3]
Reduce "brain drain" through international medical migration
Enhanced retention of physician workforce in nations with physician shortages: increased international equity and fairness (relevance, equity) [3]
Strategies to effect change

System: Top-down government control of specialty choice; national/state/provincial funding incentives for training generalist ${ }^{a}$ physicians

Accreditation: Standards that require curricula and learning experiences related to improving population health

Institution and program: Institutions and programs with a mission to train generalist physicians Individual: Educational debt forgiveness or incentive payments for individuals selecting generalist specialties

System: Top-down governmental control of health care national/state/provincial funding incentives for training physicians for rural and underserved locations Institution and program: Institutions and programs with a mission to prepare physicians for practice in rural and underserved areas

Individual: Educational debt forgiveness or incentive payments for individuals practising in rural or underserved areas

Global systems: WHO Global Code of Practice on the International Recruitment of Health Personnel [10]

${ }^{\mathrm{a}}$ Generalist specialties include primary care specialties and other general specialties in short supply, such as psychiatry and surgery

have recommended metrics to be used in the allocation of funds [33]. In Canada, the report of a consortium of organizations that addressed the future of postgraduate medical education emphasized the social accountability of physicians to the public they serve [34]. At the undergraduate medical education level, a US proposal for a "social mission" metric assessed the output of medical schools as the percentage of graduates who practice primary care, work in areas affected by a shortage of health professionals, and are members of under-represented minorities; their ranking showed that medical schools vary substantially in their contribution to these social missions [35].

Table 2 Priority 2: Physician competencies for meeting societal goals for health care and population health at a sustainable cost

\begin{tabular}{ll}
\hline Interventions & $\begin{array}{l}\text { Benefits to the health care system } \\
\text { (relevant social accountability values) }\end{array}$ \\
\hline $\begin{array}{l}\text { Ensure the quality and safety } \\
\text { of health care }\end{array}$ & $\begin{array}{l}\text { Reduced medical errors, improved } \\
\text { quality, including better patient } \\
\text { experience of care } \\
\text { (quality, cost-effectiveness) [3] }\end{array}$
\end{tabular}

Address health disparities and economic, educational, and social conditions that influence health status
Increased access to care; improved health care equity (relevance, equity) [3]
Provide resource-conscious care
Stewardship of finite health care resources

(cost-effectiveness) [3]
Strategies to effect change

Accreditation: Standards that promote quality and safety in curricula, improvement projects, and role modelling by teaching faculty; approaches to promote quality and safety improvement in the learning environment

Institution and program: Institutional- and program-level quality and safety curricula, experiences, and improvement projects

Accreditation: Standards requiring programs to set and meet aims relevant to the needs of the communities they serve; approaches to highlight and address health disparities and promote health equity [11] Institution and program: Initiatives to teach, rolemodel, and assess physician competencies important to patient advocacy $[12,13]$; measures to address health disparities $[14,15]$, social determinants of health [16], and system-level factors that create barriers to health and health care for some members of society

System: National initiatives such as the US Choosing Wisely campaign [17]

Accreditation: Accreditation standards highlighting resource-consciousness in teaching and trainee assessment 
Table 3 Priority 3: Diversity of physician workforce, and diversity and inclusiveness in the learning and working environment

\begin{tabular}{ll}
\hline Interventions & $\begin{array}{l}\text { Benefits to the health care system } \\
\text { (relevant social accountability values) }\end{array}$ \\
\hline $\begin{array}{l}\text { Promote equity in access to medical } \\
\text { education for all individuals regardless }\end{array}$ & $\begin{array}{l}\text { Increased fairness; enhanced diversity; } \\
\text { of gender or racial, ethnic, or other }\end{array}$ \\
$\begin{array}{l}\text { a physician workforce that is more } \\
\text { minority status }\end{array}$ & representative of the diversity of patients \\
(relevance, equity) [3]
\end{tabular}
minority status
Promote cultural curiosity, sensitivity, and humility
Improved experience of care; promotion of patient engagement and adherence to care

(relevance, quality, equity) [3]

Promotion of an inclusive, supportive learning environment, and of cultural sensitivity and humility in the learning environment and in graduates' future practice
Strategies to effect change

System: Affirmative action [18] (despite ongoing challenges) [19]

Accreditation: Accreditation requirements that promote diversity and inclusion [20]; standards for programs and institutions to focus on the ongoing, systematic recruitment and retention of a diverse workforce, including trainees, faculty, senior leaders, and other members of the academic community

Institution and program: Institutions with a mission to educate members of racial or ethnic minorities; holistic admissions approaches that promote diversity and inclusion [21]

Accreditation: Accreditation efforts to highlight cultural sensitivity and cultural competence in curricula, educational programming, faculty role modelling, and trainee assessment [22]

Institution and program: Institutional- and program-level efforts to teach, role-model, and assess cultural competency and sensitivity

Accreditation: Accreditation standards requiring that programs and their institutions focus on the ongoing, systematic recruitment and retention of a diverse workforce, including trainees, faculty, senior leaders, and other members of the academic community.

Institution and program: Institutional- and program-level efforts to teach, role-model, and assess inclusiveness in the learning and working environment; faculty development focused on the advancement of minorities [23]

Table 4 Priority 4: A safe, supportive learning environment that facilitates the co-production of professional development for physicians and safe and effective patient care

\begin{tabular}{ll}
\hline Ensure a respectful, supportive, & Promotion of the professional and \\
and caring environment for & personal development of learners; \\
trainees, faculty, and staff & improved work environment for \\
& learners/faculty/staff \\
& (quality, equity) [3]
\end{tabular}

Promote the safety and effectiveness of patient care in teaching settings
Appropriate supervision and oversight of care; improved experience of care for patients (quality, equity) [3]
Enhance the well-being of trainees, faculty, and other participants in the learning environment
Reduced burnout, distress, and depression in residents, faculty, and other professionals; enhanced work-life balance

(quality, equity) [3]
Accreditation: Accreditation standards against harassment of trainees; standards for trainees and others to raise concerns with their learning and working environment

Institution and program: Institutional- and program-level efforts to promote respect and caring in the learning and working environment

Accreditation: Accreditation standards limiting trainee work hours; standards to educate trainees and faculty and fatigue management; standards for appropriate supervision and faculty oversight of care in teaching settings, and equity of care regardless of patients' payer status Institution and program: Institutional- and program-level efforts to promote trainee alertness and fitness to provide care; programs to provide appropriate supervision and faculty oversight of care

Accreditation: Accreditation standards for trainee and faculty wellness programs; trainee access to care programs for physical and mental care and counselling

Institution and program: Institutional programs to provide care, counselling, and suicide prevention for trainees and faculty in distress [24]; programs to address the consequences of patient death, medical error, or other adverse events for residents and faculty [25] 
Meeting goals for social responsiveness in a competencybased postgraduate medical education system requires accrediting organizations to ensure that learning emphasizes relevant competencies, and that graduates possess the attributes to meet societal goals for health care access, population health, improved patient experience of care, and stewardship of finite health care resources [8]. In the United States, accreditation standards that will become effective in 2019 call for postgraduate medical education programs to use a "deliberate design" approach to set aims relevant to the "needs of the communities they serve, within the overall mission of their sponsoring institution, and the capabilities of physicians they intend to graduate" [36]. The new standards also include an expectation that workforce diversity be considered in program evaluation and improvement [20]. Standards like these will increase the ability of postgraduate medical education to influence change that allows the physician education system to better meet societal needs.

\section{Overcoming challenges to meeting societal expectations}

Strategies to improve the social accountability of postgraduate medical education can be impeded by time constraints, competition with other curricular components, financial limitations, and institutional resistance. The promotion of social accountability through accreditation will need to be sensitive to the fact that accredited programs and sponsoring institutions are complex adaptive systems [37] influenced by the environments in which they operate. This constrains their ability to meet the range of potentially competing demands that arise from oversight organizations and the varying interests and foci within the medical education community. For example, in the Netherlands, competing perspectives with regard to accountability, educational focus, trust, role modelling, and work-life balance emerged in discussions about the future of the nation's postgraduate medical education system [38].

There are additional challenges with regard to efforts to optimize the size and mix of the physician workforce (Table 1) in largely market-based systems such as the United States and, to a lesser degree, Canada. Accreditation cannot be used as a direct lever, as accreditors generally are enjoined from using workforce adequacy determinations in accreditation decisions [39]. In addition, while formal curricula and learning experiences can promote generalist practice and care of underserved populations, efforts to increase the supply of physicians for generalist practice and care in these populations need to address the "hidden curriculum" [40] in medical education, including the disparagement of generalist specialties [41] and the financial [42] and societal [41] reward structure for these highly needed specialties.
Globally, there are concerns with the "brain drain" that results from the migration of physicians to nations with greater freedom, higher reimbursement, and better quality of life, or to address local physician shortages [43]. In 2011, the WHO instituted a Global Code of Practice on the International Recruitment of Health Personnel, in recognition of the fact that the out-migration of physicians may hurt nations that have a high disease burden and already face shortages in their health workforce [14]. Efforts to address physician shortages in Australia and New Zealand have suggested that aligning elements of education and health systems with patient care needs is more effective than "importing" physicians [44], and in the United Arab Emirates there are efforts to train Emirati nationals to make up the next generation of physicians to serve the nation and region [45].

Addressing societal needs and expectations in postgraduate medical education is an area for additional work, including research on effective approaches and outreach to stakeholders, exploring successes and challenges, and gathering and disseminating information on effective practices for adoption or adaptation.

\section{Conclusion}

Societal responsiveness in postgraduate medical education can be achieved through a range of approaches at the system, institution, program, and individual levels. Accreditation has the potential to be effective across different national contexts and across the various dimensions of social responsiveness. A key observation is that meeting social responsiveness in a competency-based postgraduate medical education system requires accrediting organizations to ensure that learning emphasizes relevant competencies, and that graduates possess desired attributes. At the same time, there is a role for institutions that sponsor graduate medical education to provide safe and effective patient care in a supportive, humanistic learning and working environment.

\section{Abbreviations}

WFME: World Federation for Medical Education; WHO: World Health Organization

\section{Acknowledgements}

The authors would like to thank the members of the International Health

Professions Accreditation Outcomes Consortium, and everyone who

reviewed and provided feedback to this project.

\section{About this supplement}

This article has been published as part of BMC Medical Education Volume 20 Supplement 1, 2020: Current themes and challenges facing HPE accreditation in the twenty-first century. The full contents of the supplement are available online at https://bmcmedicaleducation.biomedcentral.com/articles/supplements/volume-20-supplement-1.

Authors' contributions

IP did the basic organization of the article and aggregated resources and reference. DB provided input, expanded a number of the concepts discussed, added references, and offered editorial guidance on several 
versions of the draft manuscript. Ingrid Philibert and Danielle Blouin both reviewed and approved the final version of the manuscript.

\section{Authors' information}

IP is a researcher, writer and educator in lowa City, lowa. She is visiting faculty at the Frank H. Netter MD School of Medicine at Quinnipiac University, North Haven, Connecticut, and directs the Tracking and Evaluation Core at the Great Plains IDeA CTR at the University of Nebraska Medical Center, Omaha, Nebraska.

DB is a Full Professor in the Faculty of Health Sciences (Department of Emergency Medicine), and in the Faculty of Education at Queen's University. She holds a Master of Health Professions Education degree, and a PhD in Curriculum and Instruction from the University of Illinois at Chicago. She maintains an academic clinical and education research practice.

\section{Funding}

No funding was obtained for this study.

\section{Availability of data and materials}

Not applicable.

\section{Ethics approval and consent to participate}

Not applicable.

\section{Consent for publication}

Not applicable.

\section{Competing interests}

The authors declare that they have no competing interests.

\section{Author details}

'Department of Medical Education, Frank H. Netter MD School of Medicine at Quinnipiac University, North Haven, CT, USA. ${ }^{2}$ Faculty of Health Sciences (Department of Emergency Medicine) and Faculty of Education, Queen's University, Kingston, Ontario, Canada.

\section{Published: 28 September 2020}

\section{References}

1. World Health Organization. A universal truth: no health without a workforce. Third global forum on human resources for health report. Geneva: WHO 2013. www.who.int/workforcealliance/knowledge/resources/hrhreport2013/ en/ Accessed 27 Dec 2017.

2. World Federation for Medical Education. Edinburgh declaration on medical education. 1988. Available from: http://wfme.org/publications/theedinburgh-declaration/ Accessed 27 Dec 2017.

3. Boelen C, Heck JE. Division of development of human resources for health World Health Organization. Defining and measuring the social accountability of medical schools. WHO/HRH/95.7. Geneva: World Health Organization; 1995. p. 3. Available from: http://whqlibdoc.who.int/hq/1995/ WHO_HRH_95.7.pdf Accessed 3 Mar 2018.

4. Boelen C, Woollard R. Social accountability: the extra leap to excellence for educational institutions. Med Teach. 2011;33(8):614-9.

5. Institute of Medicine (IOM). Graduate medical education that meets the nation's health needs. 2014. Available from: www.nationalacademies.org/ hmd/Reports/2014/Graduate-Medical-Education-That-Meets-the-NationsHealth-Needs.aspx Accessed 3 Mar 2018.

6. Progovac AM, Cook BL, Mullin BO, McDowell A, Sanchez RMJ, Wang Y, et al. Identifying gender minority patients' health and health care needs in administrative claims data. Health Aff (Millwood). 2018;37(3):413-20.

7. Berwick DM, Nolan TW, Whittington J. The triple aim: care, health, and cost. Health Aff (Millwood). 2008:27(3):759-69.

8. Casey SD, Mumma BE. Sex, race, and insurance status differences in hospita treatment and outcomes following out-of-hospital cardiac arrest. Resuscitation. 2018;126:125-9.

9. Pool MS, Agyemang CO, Smalbrugge M. interventions to improve social determinants of health among elderly ethnic minority groups: a review. Eur J Pub Health. 2017;27(6):1048-54

10. World Health Organization. WHO global code of practice on the international recruitment of health personnel. Geneva: WHO; 2010. Available from: www.who.int/hrh/resources/code_implementation/en/ Accessed 18 Jan 2018.

11. Bagian JP, Weiss KB. CLER evaluation committee. The overarching themes from the CLER National report of findings 2016. J Grad Med Educ. 2016:8(2 Suppl 1):21-3.

12. Kanter SL. On physician advocacy. Acad Med. 2011;86(9):1059-60.

13. Meili R, Ganem-Cuenca A, Leung JW, Zaleschuk D. The CARE model of social accountability: promoting cultural change. Acad Med. 2011;86(9): 1114-9.

14. Welch VA, Petticrew M, O'Neill J, Waters E, Armstrong R, Bhutta ZA, et al Health equity: evidence synthesis and knowledge translation methods. Syst Rev. 2013;2:43

15. Hasnain M, Massengale L, Dykens A, Figueroa E. Health disparities training in residency programs in the United States. Fam Med. 2014; 46(3):186-91.

16. Jernigan VB, Hearod JB, Tran K, Norris KC, Buchwald D. An examination of cultural competence training in US medical education guided by the tool for assessing cultural competence training. J Health Dispar Res Pract. 2016; 9(3):150-67.

17. Horwitz LI, Masica AL, Auerbach AD. Introducing choosing wisely ${ }^{\oplus}$ : next steps in improving healthcare value. J Hosp Med. 2015;10(3):187-9.

18. Mensah MO, Sommers BD. The policy argument for healthcare workforce diversity. J Gen Intern Med. 2016:31(11):1369-72.

19. Garces LM, Mickey-Pabello D. Racial diversity in the medical profession: the impact of affirmative action bans on underrepresented student of color matriculation in medical schools. J High Educ. 2015;86(2):264-94.

20. Accreditation Council for Graduate Medical Education. Draft common program requirements (residency), sections $1-V$. draft released for public comment 2018 Feb 6. Chicago: ACGME; 2018. Available from: www.acgme. org/Portals/O/PFAssets/ReviewandComment/CPR-Residency-2018-02-06-R\&C. pdf Accessed 2 April 2018.

21. Moynahan KF. The current use of United States medical licensing examination step 1 scores: holistic admissions and student well-being are in the balance. Acad Med. 2017:93(7):963-5.

22. Truong M, Paradies Y, Priest N. Interventions to improve cultural competency in healthcare: a systematic review of reviews. BMC Health Serv Res. 2014;14:99.

23. Rodriguez JE, Campbell KM, Fogarty JP, Williams RL. Underrepresented minority faculty in academic medicine: a systematic review of URM faculty development. Fam Med. 2014:46(2):100-4.

24. Ey S, Moffit M, Kinzie JM, Brunett PH. Feasibility of a comprehensive wellness and suicide prevention program: a decade of caring for physicians in training and practice. J Grad Med Educ. 2016:8(5):747-53.

25. Hu YY, Fix ML, Hevelone ND, Lipsitz SR, Greenberg CC, Weissman JS, Shapiro J. Physicians' needs in coping with emotional stressors: the case for peer support. Arch Surg. 2012;147(3):212-7.

26. Woollard B, Boelen C. Seeking impact of medical schools on health: meeting the challenges of social accountability. Med Educ. 2012;46(1):21-7.

27. Salsberg ES. Is the physician shortage real? Implications for the recommendations of the Institute of Medicine Committee on the governance and financing of graduate medical education. Acad Med. 2015; 90(9):1210-4.

28. Krist AH, Johnson RE, Callahan D, Woolf SH, Marsland D. Title VII funding and physician practice in rural or low-income areas. J Rural Health. 2005;21(1):3-11.

29. Petrany SM, Gress T, Poole D. A free clinic continuity experience during residency is associated with practice in underserved areas. J Grad Med Educ. 2017:9(5):595-9.

30. Temple J. Resident duty hours around the globe: where are we now? BMC Med Educ. 2014;14(Suppl 1):S8.

31. Philibert I, Nasca T, Brigham T, Shapiro J. Duty-hour limits and patient care and resident outcomes: can high-quality studies offer insight into complex relationships? Annu Rev Med. 2013:64:467-83.

32. Eden J, Berwick D, Wilensky G, editors. Graduate medical education that meets the nation's health needs. Washington (DC): The National Academies Press; 2014

33. Caverzagie KJ, Lane SW, Sharma N, Donnelly J, Jaeger JR, Laird-Fick H, et al. Proposed performance-based metrics for the future funding of graduate medical education: starting the conversation. Acad Med. 2017:93(7):1002-13.

34. Busing N, Harris K, MacLellan AM, Moineau G, Oandasan I, Rourke J, et al. The future of postgraduate medical education in Canada. Acad Med. 2015; 90(9):1258-63. 
35. Mullan F, Chen C, Petterson S, Kolsky G, Spagnola M. The social mission of medical education: ranking the schools. Ann Intern Med. 2010;152(12):80411 Erratum in: Ann Intern Med. 2010;153(3):212.

36. Nasca TJ, Philibert I, Brigham T, Flynn TC. The next GME accreditation system $\neg$ - rationale and benefits. N Engl J Med. 2012;366(11):1051-6.

37. Holland JH. Studying complex adaptive systems. J Syst Sci Complex. 2006; 19(1):1-8

38. Wallenburg I, van Exel J, Stolk E, Scheele F, de Bont A, Meurs P. Between trust and accountability: different perspectives on the modernization of postgraduate medical training in the Netherlands. Acad Med. 2010;85(6): 1082-90.

39. Nasca TJ, Carlson D. Graduate medical education specialty mix and geographic residency program maldistribution: is there a role for the ACGME? AMA J Ethics. 2016;18(3):258-63.

40. Woloschuk W. Wright B, McLaughlin K. Debiasing the hidden curriculum: academic equality among medical specialties. Can Fam Physician. 2011; 57(1):e26-30.

41. Brooks JV. Hostility during training: historical roots of primary care disparagement. Ann Fam Med. 2016;14(5):446-52.

42. Gagné R, Léger PT. Determinants of physicians' decisions to specialize. Health Econ. 2005;14(7):721-35.

43. Aluttis C, Bishaw T, Frank MW. The workforce for health in a globalized context - global shortages and international migration. Glob Health Action. 2014;7:23611.

44. Gorman DF. brooks PM. On solutions to the shortage of doctors in Australia and New Zealand. Med J Aust. 2009:190(3):152-6.

45. Abdel-Razig S, Alameri H. Restructuring graduate medical education to meet the health care needs of Emirati citizens. J Grad Med Educ. 2013;5(2): 195-200.

\section{Publisher's Note}

Springer Nature remains neutral with regard to jurisdictional claims in published maps and institutional affiliations.

Ready to submit your research? Choose BMC and benefit from:

- fast, convenient online submission

- thorough peer review by experienced researchers in your field

- rapid publication on acceptance

- support for research data, including large and complex data types

- gold Open Access which fosters wider collaboration and increased citations

- maximum visibility for your research: over $100 \mathrm{M}$ website views per year

At $\mathrm{BMC}$, research is always in progress.

Learn more biomedcentral.com/submissions 